\title{
Effect of Different Methods of Tillage and Conservation Farming on Nutrient Uptake, Available Nutrient in Soil and Balance Sheet of Nutrient in Finger Millet [Eleusine coracana (L.) Gaertn.] Under Rainfed Conditions
}

\author{
Ashwani Kumar Thakur* and Sudha Sidar \\ Department of Agronomy, S.G. College of Agriculture and Research Station, Jagdalpur, \\ Chhattisgarh, India \\ *Corresponding author
}

\section{A B S T R A C T}

\section{Keywords}

Finger millet, Available nitrogen, Uptake and yield.

Article Info

Accepted:

28 October 2017 Available Online: 10 December 2017

\begin{abstract}
Investigation was conducted during kharif season of 2016 at Instructional cum Research Farm, S.G. College of Agriculture and research station, Jagdalpur (C.G.). The soil of experimental field was sandy clay loam in texture and available $\mathrm{N}$ was low and, $\mathrm{P}$ and $\mathrm{K}$ were medium. The experiment was laid out in split plot design with two factors namely tillage practices and different conservation farming with three replications. The treatment consisted of three tillage practices viz. T1- Conventional tillage, T2 -Minimum tillage and $\mathrm{T}_{3}$ - Summer ploughing and five conservation farming viz. C1-Opening conservation, C2Intercropping with redgram, C3-Mulching, C4-Herbicide application, C5-Combination of all treatments $\left(\mathrm{C}_{1}+\mathrm{C}_{2}+\mathrm{C}_{3}+\mathrm{C}_{4}\right)$. Two crops were taken as a taste crop viz. finger millet $\mathrm{cv}$ "GPU 28" and redgram $c v$ "Rajeevlochan". The result revealed that summer plouging showed significantly highest available nitrogen and phosphorus but available potassium, $\mathrm{pH}$, organic carbon and EC were recorded non-significant effect. Minimum tillage recorded significantly higher soil moisture and bulk density. $\mathrm{N}$ uptake and content recorded significantly highest in summer ploughing and P uptake and content recorded higher in minimum tillage but $\mathrm{K}$ uptake was not found significant due to tillage system in grain. In straw, $\mathrm{N}$ uptake was significantly higher in summer ploughing but $\mathrm{N}$ content was higher in conventional tillage whereas, $\mathrm{P}$ and $\mathrm{K}$ were found non-significant effect in tillage practices.
\end{abstract}

\section{Introduction}

Finger millet [Eleusine coracana (L.) Gaertn.] is a stable food crop for millions of people in the semi-arid region of the world, particularly in Africa and India, and especially those who live by subsistence farming. This crop is cultivated in a wide geographical zone ranging from Senegal, Nigeria, across eastern and southern Africa, through the Middle East and into tropical Asia. Finger millet [Eleusine coracana (L.) Gaertn.] is among the most cultivated millets and belongs to the genus Elelusine, in the Chloridoidae subfamily. It is a native African crop which is also extremely important in South Asia (India and Nepal). The crop is adapted to a wide range of environments and can be grown in variety of soils with medium or low water holding capacity, but requires rainfall of at least 800 mm per annum (Thakur et al., 2016). Millets are also unique due to their short growing 
season. They can develop from planted seeds to mature, ready to harvest plants in as little as 65 days. This is important in heavily populated areas. When properly stored, whole millets will keep for two or more years (Michaelraj and Shanmugam, 2013). Finger millet seeds can be stored for a very long time without any treatment (Gowda et al., 2015). Millets are important food grains in the diets of a large section of population in India. The important small cereals among tribes of Bastar region after rice are kodo millet (Paspalum scrobiculatum L.) and finger millet [Eleusine coracana (L.) Gaertn.] (Verma and Mishra, 2010). The role of tillage in conserving soil moisture and its subsequent beneficial effect on crop productivity has long been recognized Adequate tillage operations controlled weeds and resulted in higher crop productivity, but caused more soil loss and were more capital intensive (Dogra et al., 2002). Different tillage practices significantly influenced weed population. Irrespective of the weed species, conventional tillage significantly reduced the population of weeds compared to reduced tillage and minimum tillage. The inversion of soil by following conventional tillage resulted in deeper placement of weed seeds which could not emerge out, causing a significant reduction in the population of weeds (Vijaymahantesh et al., 2013). Conservation tillage represents a broad spectrum of farming methods which are based on establishing crops in the previous crop's residue purposely left on the soil surface. The use of conservation tillage can play an important role in reducing soil erosion and improving soil quality (Uri et al., 1999) and can be an attractive to conventional tillage for farmers because of it potential to minimum labour and fuel consumption and to lower total production cost (Uri, 2000). Use of minimum tillage and no-till system may provide sufficient soil water storage to produce economical fields of crops in intensive cropping system in the northern
Great Plains. Incorporation of rice residues alters the soil environment, which is turn influences the microbial population in the soil and subsequent nutrient transformation. It is through this chain at events management of crop residues regulates the efficiency with which fertilizer, water and other reserve are used in cropping system. Crop residues (Straw mulch and plastic film mulch) should be part of integrated weed management in an agro-ecosystem which may selectivity give weed control through their physical presence on the soil surface and prevents nutrient loss, particularly nitrogen loss as volatilization and more availability of nitrogen increases vegetative growth (Bouman et al., 2007 and Iqbal et al., 2014).

\section{Materials and Methods}

\section{Site description}

The field experiment was carried out during kharif seasons of 2016-17 at Instructional cum Research Farm, S.G. College of Agriculture and research station, Jagdalpur (C.G.). Bastar (Chhattisgarh) is situated in between $19^{0} 05$ '36.55" North latitude and $81^{0} 57^{\prime} 34.69$ " East longitude with altitude ranging from $550-760 \mathrm{~m}$ above mean sea level. During khairf 2016 a total of 1740.2 $\mathrm{mm}$ rainfall was received in 78 rainy days. There was no rainfall recorded at the end of the crop season. The maximum temperature varied from $31.7^{\circ} \mathrm{C}$ in fourth week of June to $30.7^{\circ} \mathrm{C}$ in fourth week of November, whereas, minimum temperature varies from $13.8^{\circ} \mathrm{C}$ in first week of November to $13.1^{\circ} \mathrm{C}$ in second week of December.

\section{Soil physio-chemical properties}

In order to determine the physical and chemical composition of experimental plot, soil samples were collected randomly from the experimental site up to $0-15 \mathrm{~cm}$ depth 
with the help of soil auger. A composite sample was drawn from mixed representative samples by dividing repeatedly till the amount of representative samples remain about $250 \mathrm{~g}$ and then it was used for analysis (Table 1).

\section{Statistical analysis}

The data obtained on various parameters were tabulated and subjected to statistical analysis. The difference of treatment was tested with $F$ test, where $\mathrm{F}$ test shown their significance, the level of treatment were compared by critical difference at $5 \%$ level of probability. The skeleton of analysis of variance and formula used for various estimations are given by Gomez and Gomez (1984).

\section{Results and Discussion}

NPK content (\%) and NPK uptake (kg $\mathrm{ha}^{-1}$ ) in grain

\section{Nitrogen content and uptake in grain}

The data presented in Table 2 shows that the tillage and conservation farming significantly influenced the nitrogen content and uptake in finger millet. Treatment $\mathrm{T}_{3}$ (Summer plouging) showed significantly highest nitrogen content and nitrogen uptake than the conventional and minimum tillage. In case of conservation farming, treatment $\mathrm{C}_{5}$ recorded significantly highest nitrogen content and nitrogen uptake among all the conservation farming during experimentation. It was due to more dry matter production by crop and less nutrient depletion due to better management practices and subsequently more availability of nutrients to crop. These findings corroborate with those of Mukherjee (2008) and Gupta et al., (2007). Graham et al., (2002) measured significant increase in nitrogen content with increasing additions of crop residues. Similar result was obtained by Govaerts et al., (2007).

\section{Phosphorus content and uptake in grain}

Phosphorus content and phosphorus uptake was significantly affected by different treatment (Table 2). The data reveals that the treatment $\mathrm{T}_{2}$ (Minimum tillage) recorded significantly higher phosphorus content and phosphorus uptake than the $\mathrm{T}_{1}$ (conventional tillage) and $T_{3}$ (Summer tillage). In conservation farming treatment failed to show significant impact on phosphorus content in finger millet. Whereas, uptake of phosphorus showed significant effect, treatment $\mathrm{C}_{5}$ recorded significantly higher phosphorus content among all the conservation farming but it was on par with treatment $\mathrm{C}_{4}$ (Herbicide application). Unger (1991) and Matowo et al., (1999) found higher extractable phosphorus levels in minimum tillage compared to tilled soil in the top soil.

\section{Potassium content and uptake in grain}

Data shows that tillage and conservation farming unable to bring significant change in potassium content and uptake of finger millet during experimentation (Table 2).

\section{Nitrogen content and uptake in straw}

Data pertaining to nitrogen content and uptake by finger millet are presented in Table 3. Data shows that tillage methods had significant affect the nitrogen content and uptake by finger millet.

The nitrogen content and uptake was significantly highest in treatment $T_{1}$ (Conventional tillage) than the other tillage methods. Among the conservation farming nitrogen content and uptake had no significant differences in finger millet straw. The presence of organic residues on the surface induced more root growth and resulted in increased removal of nutrients by crops (Thiagalingam et al., 1991). 


\section{Phosphorus content and uptake in straw}

Data presented in Table 3 shows that tillage systems had no significant impact on P uptake and content in finger millet straw.

The phosphorus content and uptake was significantly higher in treatment $\mathrm{C}_{1}$ (Opening conservation) but it was at par with $\mathrm{C}_{2}$ (Intercropping with redgram) in phosphorus content and treatment $\mathrm{C}_{3}$ (Mulching) in phosphorus uptake remaining treatments were found non-significant effect in finger millet straw. It might be due to the better soil environment, high seed rate, and better root growth conditioned by better moisture supply, favorable soil temperatures and less impedance to root proliferation which resulted in better translocation of absorbing nutrients from soil and its translocation to plant and seed translating into higher plant growth, grain and straw yields and ultimately increased the uptake of nutrient.

\section{Potassium content and uptake in straw}

The data on potassium content and uptake of finger millet straw are presented in Table 3. The data shows that there was no significant variation due to different tillage and conservation farming in finger millet straw. In general tillage method recorded higher phosphorus content and uptake in straw as compared to their respective treatment. In case of conservation farming, phosphorus content was numerically higher in treatment $\mathrm{C}_{1}$ (Opening conservation) and higher uptake in $\mathrm{C}_{5}(\mathrm{C} 1+\mathrm{C} 2+\mathrm{C} 3+\mathrm{C} 4)$ as compare to other conservation farming. Uptake of any nutrient is the function of its content and dry matter production by the crop. Higher nutrient content in the produce and higher biomass production of finger millet might be the pertinent reason for higher uptake of nutrients. These results also reported by Mehta et al., (2005), Singh et al., (2011) and Sujatha et al., (2008).

Table.1 Initial physico-chemical properties of the soil $(0-15 \mathrm{~cm})$

\begin{tabular}{|c|c|c|}
\hline Properties & Values & Method of estimation \\
\hline \multicolumn{3}{|c|}{ A. Physical: Particle size distribution } \\
\hline Sand $(\%)$ & 65.18 & International pipette method (Black, 1965) \\
\hline Silt $(\%)$ & 10.81 & \\
\hline Clay $(\%)$ & 23.90 & \\
\hline Textural class & $\begin{array}{l}\text { Sandy clay } \\
\text { loam }\end{array}$ & \\
\hline Bulk density $\left(\mathrm{Mg} \mathrm{m}^{-3}\right)$ & 1.18 & Soil core method (Black, 1965) \\
\hline \multicolumn{3}{|l|}{ B. Chemical } \\
\hline pH (soil: water $1: 2.5$ ) & 6.20 & Glass electrode $\mathrm{pH}$ meter (Piper, 1967) \\
\hline $\mathrm{EC}\left(\mathrm{dS} \mathrm{m} \mathrm{m}^{-1}\right.$ at $\left.25^{\circ} \mathrm{C}\right)$ & 0.10 & Solubridge conductivity method, (Black,1965) \\
\hline Organic carbon $\mathrm{g} \mathrm{kg}^{-1}$ & 0.50 & $\begin{array}{l}\text { Walkley and Black's rapid titration method (Black } \\
1965)\end{array}$ \\
\hline Available $\mathrm{N}\left(\mathrm{kg} \mathrm{ha}^{-1}\right)$ & 220.00 & $\begin{array}{l}\text { Alkaline permanganate method (Subbiah and } \\
\text { Asija,1956) }\end{array}$ \\
\hline Available $\mathrm{P}_{2} \mathrm{O}_{5}\left(\mathrm{~kg} \mathrm{ha}^{-1}\right)$ & 12.99 & $\begin{array}{l}\text { By ascorbic acid method for - acidic soils (Bray, } \\
\text { 1948). }\end{array}$ \\
\hline Available $\mathrm{K}_{2} \mathrm{O}\left(\mathrm{kg} \mathrm{ha}^{-1}\right)$ & 256.01 & $\begin{array}{l}\text { Flame photometer method as described by Muhr et } \\
\text { al., (1965). }\end{array}$ \\
\hline
\end{tabular}


Table.2 N, P and K contents and uptake after harvest of finger millet (Grain) as influenced by different tillage and conservation farming

\begin{tabular}{|c|c|c|c|c|c|c|}
\hline \multirow[b]{2}{*}{ Treatment } & \multicolumn{2}{|c|}{ Nitrogen } & \multicolumn{2}{|c|}{ Phosphorus } & \multicolumn{2}{|c|}{ Potassium } \\
\hline & $\begin{array}{c}\text { Content } \\
(\%)\end{array}$ & $\begin{array}{r}\text { Uptake } \\
\left(\mathrm{Kg} \mathrm{ha}^{-1}\right)\end{array}$ & $\begin{array}{c}\text { Content } \\
(\%)\end{array}$ & $\begin{array}{r}\text { Uptake } \\
\left(\mathrm{Kg} \mathrm{ha}^{-1}\right)\end{array}$ & $\begin{array}{c}\text { Content } \\
(\%)\end{array}$ & $\begin{array}{r}\text { Uptake } \\
\left(\mathrm{Kg} \mathrm{ha}^{-1}\right)\end{array}$ \\
\hline & \multicolumn{6}{|c|}{ Tillage method } \\
\hline $\mathrm{T} 1$ & 1.53 & 37.04 & 0.24 & 5.77 & 0.46 & 11.02 \\
\hline $\mathrm{T} 2$ & 1.53 & 40.17 & 0.29 & 7.55 & 0.42 & 11.04 \\
\hline $\mathrm{T} 3$ & 1.67 & 45.15 & 0.19 & 5.10 & 0.39 & 10.24 \\
\hline$S E m \pm$ & 0.02 & 0.92 & 0.01 & 0.28 & 0.04 & 0.89 \\
\hline \multirow[t]{2}{*}{$C D$ at 0.05} & 0.09 & 3.72 & 0.04 & 1.12 & NS & NS \\
\hline & \multicolumn{6}{|c|}{ Conservation farming } \\
\hline $\mathrm{C} 1$ & 1.42 & 32.62 & 0.21 & 4.89 & 0.42 & 9.54 \\
\hline $\mathrm{C} 2$ & 1.73 & 39.21 & 0.25 & 5.51 & 0.46 & 10.17 \\
\hline $\mathrm{C} 3$ & 1.43 & 36.33 & 0.21 & 5.19 & 0.42 & 10.51 \\
\hline $\mathrm{C} 4$ & 1.43 & 39.60 & 0.26 & 7.15 & 0.42 & 11.39 \\
\hline $\mathrm{C} 5$ & 1.87 & 56.17 & 0.27 & 7.95 & 0.42 & 12.22 \\
\hline$S E m \pm$ & 0.05 & 1.39 & 0.02 & 0.66 & 0.03 & 0.78 \\
\hline$C D$ at 0.05 & 0.13 & 4.08 & NS & 1.92 & NS & NS \\
\hline
\end{tabular}

T1: Conventional tillage, T2: Minimum tillage, T3: Summer plouging, C1: Open conservation, C2: Intercropping (finger millet + redgram), C3: Mulching, C4: Herbicide application, $\mathrm{C} 5: \mathrm{C} 1+\mathrm{C} 2+\mathrm{C} 3+\mathrm{C} 4$ 
Table.3 N, P and K contents and uptake after harvest of finger millet (Straw) as influenced by different tillage and conservation farming

\begin{tabular}{|c|c|c|c|c|c|c|}
\hline \multirow[b]{2}{*}{ Treatment } & \multicolumn{2}{|c|}{ Nitrogen } & \multicolumn{2}{|c|}{ Phosphorus } & \multicolumn{2}{|c|}{ Potassium } \\
\hline & $\begin{array}{c}\text { Content } \\
(\%)\end{array}$ & $\begin{array}{r}\text { Uptake } \\
\left(\mathrm{Kg} \mathrm{ha}^{-1}\right)\end{array}$ & $\begin{array}{c}\text { Content } \\
(\%)\end{array}$ & $\begin{array}{r}\text { Uptake } \\
\left(\mathrm{Kg} \mathrm{ha}^{-1}\right)\end{array}$ & $\begin{array}{c}\text { Content } \\
(\%)\end{array}$ & $\begin{array}{r}\text { Uptake } \\
\left(\mathrm{Kg} \mathrm{ha}^{-1}\right)\end{array}$ \\
\hline & \multicolumn{6}{|c|}{ Tillage method } \\
\hline $\mathrm{T} 1$ & 0.45 & 32.41 & 0.21 & 14.88 & 0.80 & 57.73 \\
\hline $\mathrm{T} 2$ & 0.36 & 22.95 & 0.23 & 14.73 & 0.74 & 49.91 \\
\hline $\mathrm{T} 3$ & 0.35 & 25.71 & 0.23 & 16.94 & 0.69 & 51.05 \\
\hline$S E m \pm$ & 0.008 & 1.34 & 0.007 & 0.61 & 0.09 & 7.01 \\
\hline \multirow[t]{2}{*}{$C D$ at 0.05} & 0.034 & 5.39 & NS & NS & NS & NS \\
\hline & \multicolumn{6}{|c|}{ Conservation farming } \\
\hline $\mathrm{C} 1$ & 0.43 & 31.01 & 0.26 & 18.54 & 0.78 & 55.98 \\
\hline $\mathrm{C} 2$ & 0.41 & 20.31 & 0.24 & 11.98 & 0.72 & 36.15 \\
\hline $\mathrm{C} 3$ & 0.35 & 27.19 & 0.23 & 17.27 & 0.72 & 54.02 \\
\hline $\mathrm{C} 4$ & 0.37 & 26.77 & 0.20 & 14.92 & 0.76 & 56.26 \\
\hline $\mathrm{C} 5$ & 0.37 & 29.84 & 0.18 & 14.87 & 0.75 & 62.07 \\
\hline$S E m \pm$ & 0.04 & 1.34 & 0.006 & 0.67 & 0.06 & 6.77 \\
\hline$C D$ at 0.05 & NS & NS & 0.018 & 1.96 & NS & NS \\
\hline
\end{tabular}

T1: Conventional tillage, T2: Minimum tillage, T3: Summer ploughing, C1: Open conservation, C2: Intercropping (finger millet + redgram), C3: Mulching, C4: Herbicide application, $\mathrm{C} 5: \mathrm{C} 1+\mathrm{C} 2+\mathrm{C} 3+\mathrm{C} 4$ 
Int.J.Curr.Microbiol.App.Sci (2017) 6(12): 3670-3683

Table.4 Soil physico-chemical properties of finger millet as influenced by different tillage and conservation farming

\begin{tabular}{|c|c|c|c|c|c|c|c|c|}
\hline Treatment & $\begin{array}{c}\mathrm{N} \text { at } \\
\text { harvest } \\
\left(\mathrm{kg} \mathrm{ha}^{-1}\right)\end{array}$ & $\begin{array}{c}\text { P at } \\
\text { harvest } \\
\left(\mathrm{kg} \mathrm{ha}^{-1}\right) \\
\end{array}$ & $\begin{array}{c}\text { K at } \\
\text { harvest } \\
\left(\mathrm{kg} \mathrm{ha}^{-1}\right) \\
\end{array}$ & $\begin{array}{c}\text { Soil } \\
\text { moisture \% } \\
\text { at harvest } \\
\end{array}$ & $\begin{array}{c}\text { Bulk } \\
\text { density } \\
\left(\mathrm{g} \mathrm{cm}^{-3}\right)\end{array}$ & $\begin{array}{c}\text { pH at } \\
\text { harvest }\end{array}$ & $\begin{array}{c}\text { OC \% at } \\
\text { harvest }\end{array}$ & $\begin{array}{c}\text { EC at } \\
\text { harvest }\end{array}$ \\
\hline \multicolumn{9}{|c|}{ Tillage Methods } \\
\hline $\mathrm{T} 1$ & 195.69 & 15.16 & 175.75 & 12.29 & 1.38 & 5.69 & 0.70 & 0.19 \\
\hline $\mathrm{T} 2$ & 193.18 & 12.54 & 172.22 & 17.16 & 1.45 & 5.72 & 0.74 & 0.19 \\
\hline $\mathrm{T} 3$ & 261.33 & 20.38 & 185.02 & 15.11 & 1.42 & 5.92 & 0.76 & 0.20 \\
\hline$S E m \pm$ & 5.99 & 1.26 & 6.53 & 0.71 & 0.01 & 0.06 & 0.04 & 0.01 \\
\hline$C D$ at 0.05 & 24.16 & 5.09 & NS & 0.72 & 0.02 & NS & NS & NS \\
\hline \multicolumn{9}{|c|}{ Conservation farming } \\
\hline $\mathrm{C} 1$ & 197.22 & 20.04 & 179.21 & 13.42 & 1.41 & 0.64 & 6.19 & 0.21 \\
\hline $\mathrm{C} 2$ & 240.43 & 15.68 & 175.90 & 12.05 & 1.41 & 0.68 & 6.13 & 0.21 \\
\hline C3 & 202.80 & 14.81 & 173.69 & 19.65 & 1.42 & 0.81 & 5.73 & 0.19 \\
\hline $\mathrm{C} 4$ & 201.0 & 13.94 & 166.70 & 12.93 & 1.41 & 0.67 & 5.81 & 0.19 \\
\hline $\mathrm{C} 5$ & 241.82 & 15.68 & 192.82 & 16.21 & 1.44 & 0.86 & 5.01 & 0.18 \\
\hline SEm \pm & 9.05 & 2.67 & 6.53 & 0.72 & 0.01 & 0.04 & 0.09 & 0.01 \\
\hline$C D$ at 0.05 & 26.58 & NS & NS & 2.12 & NS & 0.13 & 0.25 & NS \\
\hline
\end{tabular}

T1: Conventional tillage, T2: Minimum tillage, T3: Summer ploughing, C1: Open conservation, C2: Intercropping (finger millet + redgram), C3: Mulching, C4: Herbicide application, C5: $\mathrm{C} 1+\mathrm{C} 2+\mathrm{C} 3+\mathrm{C} 4$ 
Table.5 Balance sheet of soil available Nitrogen $\left(\mathrm{kg} \mathrm{ha}^{-1}\right)$ influenced by different tillage and conservation farming

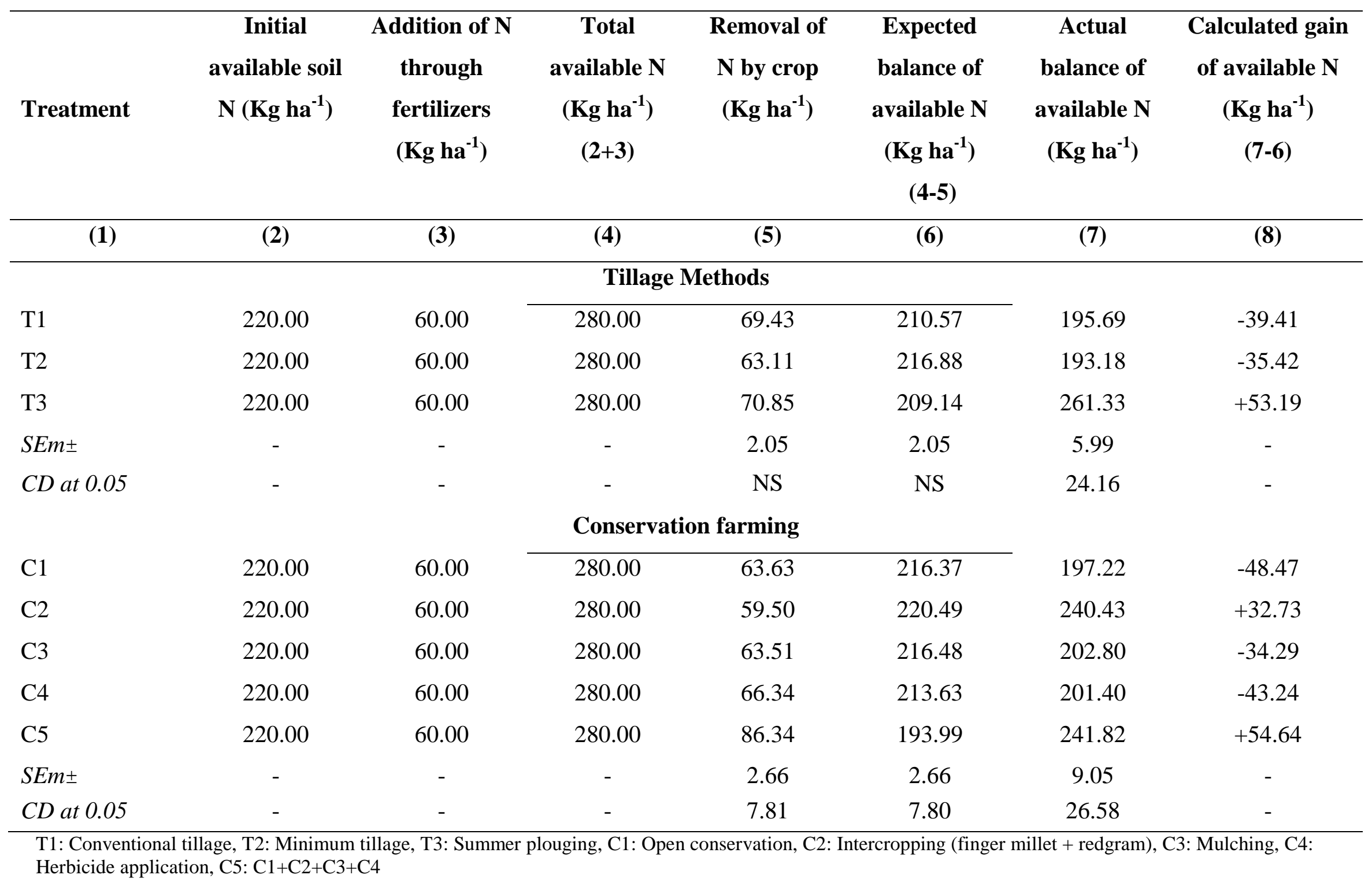


Table.6 Balance sheet of soil available Phosphorus $\left(\mathrm{kg} \mathrm{ha}^{-1}\right)$ influenced by different tillage and conservation farming

\begin{tabular}{|c|c|c|c|c|c|c|c|}
\hline Treatment & $\begin{array}{c}\text { Initial } \\
\text { available soil } \\
\text { P } \\
\left(\mathrm{Kg} \mathrm{ha}^{-1}\right)\end{array}$ & $\begin{array}{c}\text { Addition of } P \\
\text { through } \\
\text { fertilizers } \\
\left(\mathrm{Kg} \mathrm{ha}^{-1}\right)\end{array}$ & $\begin{array}{c}\text { Total } \\
\text { available P } \\
\left(\mathrm{Kg} \mathrm{ha}^{-1}\right) \\
(2+3)\end{array}$ & $\begin{array}{c}\text { Removal of } P \\
\text { by crop } \\
\left(\mathrm{Kg} \mathrm{ha}^{-1}\right)\end{array}$ & $\begin{array}{c}\text { Expected } \\
\text { balance of } \\
\text { available P } \\
\left(\mathrm{Kg} \mathrm{ha}^{-1}\right) \\
(4-5)\end{array}$ & $\begin{array}{c}\text { Actual } \\
\text { balance of } \\
\text { available P } \\
\left(\mathrm{Kg} \mathrm{ha}^{-1}\right)\end{array}$ & $\begin{array}{c}\text { Calculated grain } \\
\text { of available } P \\
\left(\mathrm{Kg} \mathrm{ha}^{-1}\right) \\
(7-6)\end{array}$ \\
\hline (1) & (2) & (3) & (4) & (5) & (6) & (7) & (8) \\
\hline \multicolumn{8}{|c|}{ Tillage Methods } \\
\hline $\mathrm{T} 1$ & 12.99 & 40.00 & 52.99 & 20.65 & 71.75 & 15.16 & -56.60 \\
\hline $\mathrm{T} 2$ & 12.99 & 40.00 & 52.99 & 22.28 & 70.13 & 12.54 & -57.58 \\
\hline $\mathrm{T} 3$ & 12.99 & 40.00 & 52.99 & 22.04 & 70.36 & 20.38 & -49.98 \\
\hline$S E m \pm$ & - & - & - & 0.44 & 0.44 & 1.26 & - \\
\hline$C D$ at 0.05 & - & - & - & NS & NS & 5.09 & - \\
\hline \multicolumn{8}{|c|}{ Conservation farming } \\
\hline $\mathrm{C} 1$ & 12.99 & 40.00 & 52.99 & 23.44 & 68.96 & 20.04 & -48.93 \\
\hline $\mathrm{C} 2$ & 12.99 & 40.00 & 52.99 & 17.49 & 74.91 & 15.68 & -59.23 \\
\hline $\mathrm{C} 3$ & 12.99 & 40.00 & 52.99 & 22.46 & 69.94 & 14.81 & -55.13 \\
\hline $\mathrm{C} 4$ & 12.99 & 40.00 & 52.99 & 22.06 & 70.34 & 13.94 & -56.40 \\
\hline C5 & 12.99 & 40.00 & 52.99 & 22.82 & 69.58 & 15.68 & -53.90 \\
\hline$S E m \pm$ & - & - & - & 0.76 & 0.76 & 2.67 & - \\
\hline$C D$ at 0.05 & - & - & - & 2.23 & 2.23 & NS & - \\
\hline
\end{tabular}

T1: Conventional tillage, T2: Minimum tillage, T3: Summer ploughing, C1: Open conservation, C2: Intercropping (finger millet + redgram), C3: Mulching, C4: Herbicide application, $\mathrm{C} 5: \mathrm{C} 1+\mathrm{C} 2+\mathrm{C} 3+\mathrm{C} 4$ 
Table.7 Balance sheet of soil available Potassium $\left(\mathrm{kg} \mathrm{ha}^{-1}\right)$ influenced by different tillage and conservation farming

\begin{tabular}{|c|c|c|c|c|c|c|c|}
\hline Treatment & $\begin{array}{c}\text { Initial } \\
\text { available soil } \\
\text { K } \\
\left(\mathrm{Kg} \mathrm{ha}^{-1}\right)\end{array}$ & $\begin{array}{c}\text { Addition of K } \\
\text { through } \\
\text { fertilizers } \\
\left(\mathrm{Kg} \mathrm{ha}^{-1}\right)\end{array}$ & $\begin{array}{c}\text { Total } \\
\text { available K } \\
\left(\mathrm{Kg} \mathrm{ha}^{-1}\right) \\
(2+3)\end{array}$ & $\begin{array}{c}\text { Removal of } K \\
\text { by crop } \\
\left(\mathrm{Kg} \mathrm{ha}^{-1}\right)\end{array}$ & $\begin{array}{c}\text { Expected } \\
\text { balance of } \\
\text { available K } \\
\left(\mathrm{Kg} \mathrm{ha}^{-1}\right) \\
(4-5)\end{array}$ & $\begin{array}{c}\text { Actual } \\
\text { balance of } \\
\text { available K } \\
\left(\mathrm{Kg} \mathrm{ha}^{-1}\right)\end{array}$ & $\begin{array}{c}\text { Calculated grain } \\
\text { of available } \mathrm{K} \\
\left(\mathrm{Kg} \mathrm{ha}^{-1}\right) \\
(7-6)\end{array}$ \\
\hline (1) & (2) & (3) & (4) & (5) & (6) & (7) & (8) \\
\hline \multicolumn{8}{|c|}{ Tillage Methods } \\
\hline $\mathrm{T} 1$ & 346.92 & 30.00 & 376.92 & 68.75 & 308.94 & 175.75 & -132.43 \\
\hline $\mathrm{T} 2$ & 346.92 & 30.00 & 376.92 & 60.95 & 315.67 & 172.22 & -143.72 \\
\hline $\mathrm{T} 3$ & 346.92 & 30.00 & 376.92 & 61.29 & 315.63 & 185.02 & -130.61 \\
\hline SEm \pm & - & - & - & 7.61 & 7.61 & 6.53 & - \\
\hline$C D$ at 0.05 & - & - & - & NS & NS & NS & - \\
\hline \multicolumn{8}{|c|}{ Conservation farming } \\
\hline $\mathrm{C} 1$ & 346.92 & 30.00 & 376.92 & 65.52 & 311.40 & 179.21 & -132.14 \\
\hline $\mathrm{C} 2$ & 346.92 & 30.00 & 376.92 & 46.32 & 330.60 & 175.90 & -154.71 \\
\hline $\mathrm{C} 3$ & 346.92 & 30.00 & 376.92 & 64.53 & 312.39 & 173.69 & -138.71 \\
\hline $\mathrm{C} 4$ & 346.92 & 30.00 & 376.92 & 67.66 & 309.26 & 166.70 & -142.57 \\
\hline $\mathrm{C} 5$ & 346.92 & 30.00 & 376.92 & 74.29 & 302.63 & 192.82 & -109.80 \\
\hline SEm \pm & - & - & - & 7.08 & 7.08 & 9.48 & - \\
\hline$C D$ at 0.05 & - & - & - & NS & NS & NS & - \\
\hline
\end{tabular}

T1: Conventional tillage, T2: Minimum tillage, T3: Summer ploughing, C1: Open conservation, C2: Intercropping (finger millet redgram), C3: Mulching, C4: Herbicide application, $\mathrm{C} 5: \mathrm{C} 1+\mathrm{C} 2+\mathrm{C} 3+\mathrm{C} 4$ 


\section{pH, OC and EC}

$\mathrm{pH}, \mathrm{OC}$ and EC in soil of finger millet plot as influenced by different tillage and conservation farmings are presented in Table 4. The data revealed that in tillage system $\mathrm{pH}, \mathrm{OC}$ and $\mathrm{EC}$ could not produce significantly impact in finger millet field. Kumar and Yadav (2005) reported that value of organic carbon, electrical conductivity and soil $\mathrm{pH}$ were either equal or slightly higher than their initial values due to tillage treatment. Jacobs et al., (2009) found that minimum tillage, compared with conventional tillage, did not only improve aggregates stability but also increased the concentration in the upper $5-8 \mathrm{~cm}$ soil depth In case of conservation farming, $\mathrm{pH}, \mathrm{OC}$ and $\mathrm{EC}$ recorded significantly effect, $\mathrm{pH}$ recorded significantly higher in treatment $\mathrm{C}_{1}$ (Opening conservation) which was at par with treatment $\mathrm{C}_{2}$ (Intercropping with redgram) and lowest $\mathrm{pH}$ was recorded in treatment $\mathrm{C}_{5}$. Whereas, in organic carbon in conservation farming, treatment $\mathrm{C}_{3}$ recorded significantly higher organic carbon among all the treatments. EC could not produce significant impact in soil of finger millet field during experimentation.

The findings are in agreement with those of Madari et al., (2005) and Riley et al., (2005) who reported that conservation tillage with residue cover had higher total organic carbon in soil aggregates than traditional tillage. Osunbitan et al., (2005) examined the effects of tillage on bulk density, hydraulic conductivity and strength of a loam sand soil. They found that the bulk density and penetration resistance of surface soil decreased with increase in the intensity of soil loosening by tillage operation. Residue retention and direct seeding have a major influence on improving water infiltration, organic matter content and fertility of a soil (Wall, 1999). Mulch cover shields the soil from solar radiation thereby reducing evaporation from the soil. Soil biota increase under mulched soil environment thereby improving nutrient cycling and organic matter build up over a period of several years (Holland, 2004).

\section{Available NPK in finger millet}

The data on available N, P and $\mathrm{K}$ in soil of finger millet field as influenced by different tillage and conservation farmings are presented in Table 4. The findings revealed that treatment $\mathrm{T}_{3}$ (Summer plouging) recorded significantly higher available $\mathrm{N}$ and $\mathrm{P}$ but $\mathrm{K}$ could not give significant influence in tillage methods in finger millet field. As regard to conservation farming treatment $\mathrm{C}_{5}$ recorded significantly highest available $\mathrm{N}$ which was at par with in treatment $\mathrm{C}_{2}$ (Intercropping with redgram). Available $\mathrm{P}$ and available $\mathrm{K}$ could not give significantly influence in conservation farming treatment in finger millet. Varalakshmi (2005) observed that the higher available phosphorus might be due to the release of organic acids during microbial decomposition of organic matter which helped in the solubility of native phosphates thus increasing available phosphorus. The applied organic matter may have led to formation of coating on the sesquioxide clay minerals, because of which the phosphate fixing capacity of soil is reduced in manure treated plots compared to inorganic fertilizer alone.

Roldan et al., (2005) observed that the accumulation of $\mathrm{P}$ at the top soil in zero tillage and minimum tillage can be explained by the limited downward movement of particle bound $\mathrm{P}$ in no-till and minimum-till soils and the upward movement of nutrients from deeper layers through uptake by roots. Available potassium increased significantly in the toplayer of shallow tilled soil, but not in the $10-20 \mathrm{~cm}$ layer compared with ploughed soil (Comia et al., 1994).

\section{Balance sheet of available nitrogen $\left(\mathrm{Kg} \mathrm{ha}^{-1}\right)$}

The data on balance sheet of available $\mathrm{N}$ of finger millet field as influenced by different tillage and conservation farming presented in Table 5, the findings revealed that actual balance of available nitrogen, was significantly highest in treatment $T_{2}$ (Minimum tillage) than the other tillage treatments. Removal of nitrogen by crop, expected balance of available 
$\mathrm{N}$ and calculated gain of available $\mathrm{N}$ was found non-significant effect due to tillage treatments. Conservation farming brought significantly, where treatment $\mathrm{C}_{5}(\mathrm{C} 1+\mathrm{C} 2+\mathrm{C} 3+\mathrm{C} 4)$ recorded significantly higher removal of $\mathrm{N}$ by crop and actual balance of available $\mathrm{N}$ but actual balance of available $\mathrm{N}$ was at par with $\mathrm{C}_{2}$ (Intercropping with redgram). Expected balance of available $\mathrm{N}$ was significantly higher in treatment $\mathrm{C}_{2}$ (Intercropping with redgram) which was at par with $\mathrm{C}_{3}$ (Mulching), $\mathrm{C}_{1}$ (Opening conservation) and $\mathrm{C}_{4}$ (Herbicide application) in conservation farming.

Balance sheet of available phosphorus (Kg $\mathrm{ha}^{-1}$ )

Data presented in Table 6 reveals that removal of $\mathrm{P}$ by crop and expected balance of available $P$ in different tillage and actual balance of available $\mathrm{P}$ and calculated gain available $\mathrm{P}$ in conservation farming show non-significant differences. Actual balance of available $\mathrm{P}$ was significantly highest in treatment $\mathrm{T}_{3}$ (Summer plouging) whereas, treatment $\mathrm{T}_{1}$ (Conventional tillage) recorded significantly higher calculated gain available $\mathrm{P}$ in finger millet field which was at par with treatment $\mathrm{T}_{2}$ (Minimum tillage) in tillage methods. In conservation farmings, $\mathrm{C}_{1}$ (Opening conservation) recorded significantly higher removal of $\mathrm{P}$ by crop which was on par with $\mathrm{C}_{5}$ (combination of all treatment), $\mathrm{C}_{3}$ (Mulching) and $\mathrm{C}_{4}$ (Herbicide application) and lowest removal of $\mathrm{P}$ by crop was recorded in conservation farming $\mathrm{C}_{2}$ (Intercropping with redgram). Expected balance of available $\mathrm{P}$ recorded significantly highest $\mathrm{C}_{2}$ (Intercropping with redgram) among all the conservation farming treatments.

Balance sheet of available potassium (Kg $\mathrm{ha}^{-1}$ )

The data on balance sheet of soil available $\mathrm{K}$ in finger millet field as influenced by different tillage and conservation farming are given in Table 7 and the finding revealed that removal of $\mathrm{K}$ by crop expected balance of available $\mathrm{K}$, actual balance of available $\mathrm{K}$ and calculated gain of available $\mathrm{K}$ remained unaffected due to tillage and conservation farming.

Summer plouging showed significantly highest available nitrogen, phosphorus but available potassium, $\mathrm{pH}$ and EC was recorded nonsignificant. Tillage recorded significantly higher soil moisture over conventional tillage, but bulk density was significantly highest in minimum tillage. Tillage system recorded significant effect $\mathrm{N}$ uptake and content in summer plouging and $\mathrm{P}$ uptake and content in minimum tillage but $\mathrm{K}$ uptake was not found significant effect due to tillage system in grain. In straw $\mathrm{N}$ uptake was significantly affected in summer plouging but $\mathrm{N}$ content was higher in conventional tillage, $\mathrm{P}$ and $\mathrm{K}$ was found non-significant in tillage practices.

Available $\mathrm{N}$ was significantly higher in combination of all treatments but available $\mathrm{P}$, $\mathrm{K}$, bulk density and EC recorded nonsignificantly. In conservation farming system mulching recorded significantly higher soil moisture and organic carbon but higher $\mathrm{pH}, \mathrm{N}$ uptake and content value was recorded significantly higher intercropping with finger millet + redgram, $\mathrm{P}$ uptake significantly higher in combination of all treatments. $\mathrm{P}$ content, $\mathrm{K}$ uptake and $\mathrm{K}$ content observed nonsignificantly effect during experimentation in grain. In case of conservation farming system $\mathrm{P}$ uptake and content was significant higher in mulch and opening conservation.

\section{References}

Black, C. A. 1965. Method of soil analysis. Amar. Agron. Inc. Madeson, Wisconsin, USA. pp. 131-137.

Bouman, B.A.M., Humphreys, E., Tuong, T.P. and Barker, R. 2007. Rice and Water. Advances in Agronomy, 92: 187-237.

Bray, R.H. 1948. Requirements for successful soil test. Soil Science, 66:83-89.

Comia, R.A., Stenberg, M., Nelson, P., Rydberg, T., Hakansson, I., 1994. Soil and crop responses to different tillage systems. Soil Tillage Res. 29, 335-355. 
Dogra, P., Joshi B. P. and Sharma, N. K. 2002. Economic analysis of tillage practices for maize cultivation in the Himalayan humid subtropics. Ind. J. Soil Conserv., 30(2): 172-178.

Gomez, K.A. and Gomez, A.A. 1984. Statistical procedures for agricultural research. A Willey- Inter Sci. Publication. John Willey \& Sons, New York.

Gowda, P.H., Prasad, P.V., Sangamesh, V., Angadi., Rangappa, U.M. and Wagle, P. 2015. Finger millet: An alternative crop for the southern high plains. Ame. J. Plant Sci., 6: 2686-2691.

Graham, M.H., Haynes, R.J., and Meyer, J.H. 2002. Soil organic matter content and quality: effects of fertilizer applications, burning and trash retention on a long-term sugarcane experiment in South Africa. Soil Biol. Biochem., 34: 93-102.

Gupta, M., A. S. Bali, B. C. Sharma, D. Kachroo and R. Bharat (2007). Productivity, nutrient uptake and economics of wheat under various tillage and fertilizer management practices. Indian Journal of Agronomy, 52: 127130.

Holland, J.M. 2004. The environmental consequences of adopting conservational tillage in Europe: reviewing the evidence. Agricultural Ecosystem Environment 103, $1-25$.

Jacobs, A., Rauber, R. and Ludwig, B. 2009.Impact of reduced tillage on carbon and nitrogen storage. Soil and Till. Res., 102: 158-164.

Kumar, R., and Yadav, D. S. 2005. Effect of zero and minimum tillage in conjunction with nitrogen management in wheat after rice. Ind. J. Agro. 50(1): 54-57.

Madari, B., Machado, P. L. O. A., Torres, E., Andrade, A. G. de and Valencia, L. I. O. 2005. No tillage and crop rotation effects on soil aggregation and organic carbon in a Rhodic Ferralsol from southern Brazil. Soil and Till., 80: 185-200.

Matowo, P.R., Pierzynski, G.M., Whitney, D., and Lamond, R.E. 1999. Soil chemical properties as influenced by tillage and nitrogen source, placement, and rates after 10 years of continuous sorghum. Soil Till. Res., 50:11-19.

Mehta, Y. K., Shaktawat, M. S. and Singh, S. M. 2005. Influenced of sulfer, phosphorus and FYM on yield attributes and yield of maize (Zea mays) in south Rajasthan conditions. Ind. J. Agron. 50(3): 203-205.

Michaelraj. S. J. and Shanmugam, A. 2013. A study on millets cultivation in Karur district of Tamilnadu. Int. J. Manage. Res. Rev., 2(4): 2167-2179.

Muhr, G.R., Datta, N.P., Subramoney, H., Leley, V.K. and Donahue, R.L. 1965. Soil testing in India. United States Agronomy for International development mission on India, New Delhi.

Mukherjee, D. (2008). Effect of tillage practices and fertility levels on the performance of Wheat (Triticum aestivum) under mid hill condition of West Bengal. Indian Journal of Agricultural Sciences, 78(12) : 103841.

Osunbitan, J. A., Oyedele. D. J. and Adekalu, K. O. 2005. Tillage effects on bulk density hydraulic conductivity and strength of a loam sand soil in southwestern Nigeria. Soil and Till. Res., 82: 57-64.

Piper, C. S. 1967. Soil and plant analysis. Bombayl New Delhi, Asia publishing house. 30-38.

Riley, H.C.F., Bleken, M.A. Abrahamsen, S., Bergjord, A.K. and Bakken, A.K. 2005. Effects of alternative tillage systems on soil quality and yield of spring cereals on silty clay loam and sandy loam soils in cool, wet climate of central Norway. Soil Till. Res., 80: 79-93.

Roldan, A., Salinas-Garc'1a, J. R., Alguacil, M. M., D'1az, E. and Caravaca, F. 2005. Soil enzyme activities suggest advantages of conservation tillage practices in sorghum cultivation under subtropical conditions. Geoderma, vol. 129, no. 3-4, pp. 178185.

Singh, G. Sharma, G. L. and Golada, S. L. 2011. Effect of enriched FYM with fertilizers \& biofertilizers on yield, 
harvest index, protein, nitrogen and phosphorous content in grains. J. of Progressive Agriculture., 2(3): 65-67.

Subbiah, B. V. and Asija, G. L. 1956. A rapid method for the estimation of nitrogen in soils. Current Science, 26: 259-260.

Sujatha, Lingaraju, M.G., Y. B. Palled and Ashalatha, K. V. 2008. Importance of integrated nutrient management practices in maize under rainfed condition, Karnataka J. of Agri. Sci., 21(3):334-338.

Thakur, A. K., Kumar, P., Salam, P., Patel, R. K. and Netam, C. R. 2016. Effect of different sowing methods, Nutrient Management and seed priming on growth, yield attributing characters, yield and economics of finger millet (Eleucine coracana L.) at Bastar Plateau. J. of Pure and Applied Microbiology, Vol. 10(1), p407-415.

Thiagalingam, K., N. Gould and P. Watson (1991). Effect of tillage on rainfed maize and soybean yield and the nitrogen fertilizer requirements for maize. Soil and Tillage Research, 19 : 47-54.

Unger, P.W. 1996. Soil bulk density, penetration resistance, and hydraulic conductivity under controlled traffic conditions. Soil and till. Res., 37(1): 6775.

Uri, N. D. 2000. An evaluation of the economic benefits and. costs of conservation tillage. Environmental Geology, 39: 238-248.

Uri, N.D.T., Wood, J.D. and Sanabria, J. 1999. The environmental benefits and costs of conservation tillage Environmental Geology, 38: 111-125.

Varalakshmi, L.R., Srinivasamurthy, C.A. and Bhaskar, S. 2005. Effect of integrated use of organic manures and inorganic fertilizers on organic carbon, available $\mathrm{N}$, $\mathrm{P}$ and $\mathrm{K}$ in sustaining productivity of groundnut-finger millet cropping system. Journal of Indian Society of Soil Science, 53: 315-318.

Verma, P.K. and Mishra, N. 2010. Traditional techniques of processing on minor millets in Bastar district of Chhattisgarh, India. Res. J. Agricultural Science, 1 (4): 465467.

Vijaymahantesh, Nanjappa, H.V. and Ramachandrappa, B.K. 2013. Effect of tillage and nutrient management practices on weed dynamics and yield of fingermillet under rainfed pigeonpeafinger millet system in Alfisols of Southern India. African J. Agri. Res., 8 (21): 2470-2475.

Wall, P.C. 1999. Experiences with crop residue cover and direct seeding in the Bolivian highlands. Mt-res-dev. Berkeley, Calif.: University of California Press. 19 (4): 313 317.

Yakadri, M. and Reddy, A.P.K. 2009. Productivity of pearl millet (Pennisetum glaucum L.) as influenced by planting pattern and nitrogen levels during summer. Journal of Research ANGRAU, 37: 34-37.

\section{How to cite this article:}

Ashwani Kumar Thakur and Sudha Sidar. 2017. Effect of Different Methods of Tillage and Conservation Farming on Nutrient Uptake, Available Nutrient in Soil and Balance Sheet of Nutrient in Finger Millet [Eleusine coracana (L.) Gaertn.] Under Rainfed Conditions. Int.J.Curr.Microbiol.App.Sci. 6(12): 3670-3683. doi: https://doi.org/10.20546/ijcmas.2017.612.424 